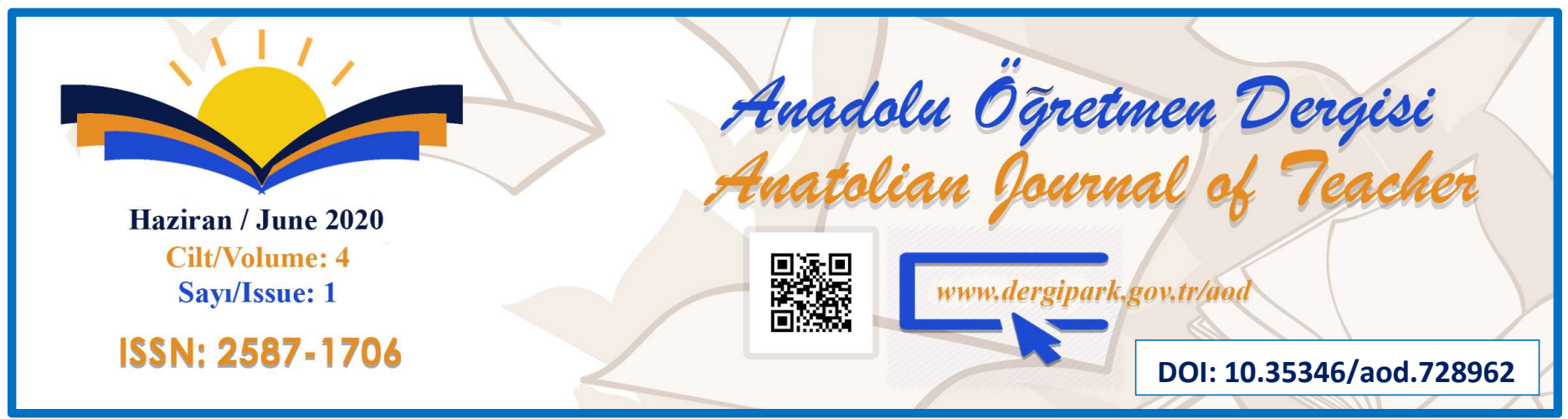

\title{
VİRÜS KONUSUNUN ORTAÖĞRETİM ÖĞRETIMM PROGRAMLARINDAKİ YERİ
}

\author{
Sema TAKMAZ, Doç. Dr. Miraç YILMAZ \\ Hacettepe Üniversitesi, Eğitim Fakültesi, Matematik ve Fen Bilimleri Eğitimi Bölümü, Biyoloji Eğitimi \\ Anabilim Dalı, Ankara, sema.takmaz@gmail.com, mirac@hacettepe.edu.tr
}

\begin{abstract}
ÖZET
Virüslerle ilgili bilinçlenme ve viral hastalıklarla mücadelede, eğitimin etkili olabilmesi ve öğretim amaçlarının yüksek düzeyde gerçekleştirebilmesi için, okullarda uygulanan öğretim programlarının önemi yadsınamaz. Bu araştırmada ortaöğretimde virüs konusunun, biyoloji ve sağlık bilgisi öğretim programlarındaki yerinin incelenmesi amaçlanmıştır. Bu bağlamda virüs konusunun yer aldığı ortaöğretim biyoloji ve sağlık bilgisi dersi öğretim programları sınıf düzeyi, ders saati, içerik ve kazanımlar açısından değerlendirilmiştir. Araştırma nitel yöntemlerden doküman incelemesi ile gerçekleștirilmiştir. Doküman olarak, Milli Eğitim Bakanlığı'nca uygulanmakta olan biyoloji ve sağlık bilgisi dersleri öğretim programları ele alınmış ve içerik analizine tabii tutulmuştur. Çalışmadan elde edilen sonuçlara göre, ortaöğretim biyoloji ve sağlık bilgisi dersi öğretim programlarında virüslere ilişkin kazanım sayısının ve ayrılan sürenin çok az olduğu, ayrıca genelde virüsler konusunun dönem sonuna tekabül etmesinin konunun öğrenilmesinde dezavantajlı durumlar yaratabileceği ortaya çıkmaktadır. Sonuçlarımıza göre viral etkenli pandemilerin yaşandığı günümüzde, insan sağlığı ve hayatına önemli etkileri olan virüslerle ilgili olarak, tüm lise öğrencilerinin sadece 9. sınıfta oldukça yüzeysel bilgiler almakta olduğu görülmektedir. Ayrıca 11 ve 12. Sinıflarda sadece biyoloji dersini seçerek alabilen öğrencilerin virüslerle ilgili bazı üst bilgilere ulaşabildiği tespit edilmiştir.
\end{abstract}

Anahtar sözcükler: Virüs, biyoloji, sağlık, öğretim programı, ortaöğretim.

\section{INVESTIGATION OF VIRUS TOPIC IN SECONDARY EDUCATION IN TERMS OF CURRICULUMS}

\begin{abstract}
For awareness about viruses and in defense against viral diseases, effective of education and for the teaching objectives to be achieved at a high level, the importance of the curriculum applied in schools cannot be denied. In this study, aimed to examine of virus topic, in biology and health curriculums of secondary education. In this context, biology and health lessons curriculums in secondary education, in which the topic of virus is included, has been evaluated in terms of grade level, course hour, content and acquisitions. Research, it was done by document analysis from qualitative methods. As a document, the curriculums of biology and health lessons, which are being implemented by the Ministry of National Education, have been considered and content analysis was done. According to the results obtained, it was determined that the acquisitions amount and duration of viruses in the secondary education biology and health education curriculum is very low. In addition, viruses is processed at the end of the period, which creates disadvantageous situations in learning. With the results of our study, today when viral pandemics are experienced, that have significant effects on human health and life, all high school students receive very superficial information only in the 9 th grade regarding viruses. Only In the 11 th and 12 th grades, students who can take biology lessons, can access some more information about viruses.
\end{abstract}

Key Words: Virus, biology, health, curriculum, secondary education.

${ }^{1}$ Bu çalışma ilk yazarın 2019 yılında tamamlanmış olan Yüksek Lisans tezinin bir kısmından yayına hazırlanmıştır. 


\section{GIRIŞ}

Gelişen dünyada, virüslerin pozitif ve negatif olarak barındırdıkları potansiyellerin, gittikçe daha fazla ortaya çıktığı gözlenmektedir. Nitekim, viral etkenli pandemilerin görünmeye başlandığı günümüzde virüse dair bilinçlenme ve sebep oldukları hastalıklarla mücadele yöntemleri günlük hayatımızdaki en önemli konulardan biri haline gelmiştir. $\mathrm{Bu}$ durum örgün eğitim içerisinde, virüslerle ilgili eğitimin etkili olabilmesi ve virüslere ilişkin öğretim amaçlarının yüksek düzeyde gerçekleşebilmesi için, okullarda uygulanan öğretim programlarının önemini arttırmaktadır. Günümüzde virüslerle ilgili yaşanan gelişmeler, biyoloji ve sağlık bilgisi öğretimi adına gerçekleştirilen eğitim-öğretim faaliyetlerinin, kapsamlı şekilde gözden geçirilmesini ve değerlendirilmesini gerektirmektedir.

Biyoloji alanında yer alan önemli kavramlardan biri olan virüs; sağlık, tarım, çevre, gen teknolojisi vb. gibi pek çok farklı alanda sık sık karşımıza çıkmaktadır. Virüslerin farklı canlıları enfekte etme, hastalık durumu yaratma ve tedavi sürecinde aşı olarak kullanılmaları, onları canlılar için oldukça önemli hale getirmektedir. Ayrıca biyolojik silah veya genetik mühendisliğindeki kullanım alanları da dikkatleri çekmektedir (Topal, 2006). Bu nedenlerle özellikle günlük hayatımızda çok sık karşımıza çıkan viral hastalıklarla ilgili olarak hayatımızı kolaylaştıracak ve sağlıklı kılacak bilgilerin güncelliğinin sürekli gözden geçirilmesi ve gerekli görüldükçe eğitim sistemlerine dahil edilmesi önem taşımaktadır.

Araştırmacılara göre sağlık, çevre gibi hayati önem taşıyan konularda bireylerin bilinç kazanması ancak etkili, zamanın şartlarına uygun, yenilenebilen bir biyoloji eğitimi programı ile mümkündür (Çetin \& Başbay, 2015). Bu amaçla biyoloji bilgilerini içeren öğretim programlarının yenilenip kapsam, etkililik ve kullanılabilir bilgi açılarından aktif hale getirilmesi kaçınılmaz bir gereklilik olarak görülebilmektedir. Çeşitli araştırmalarda öğretim programlarına ilişkin dile getirilen içerik, ders saati, uygulama, öğretim etkinlikleri, değerlendirme ve hizmet içi eğitimlerle ilgili geniş beklentiler olduğu bildirilmektedir (Yeşilyurt \& Gül, 2008; Aydoğdu, 2010; Horasan, 2012). Bu beklentilerin karşılanabilmesi için, öncelikle varolan öğretim programlarının incelenmesi ve geliştirilmesine yönelik önerilerin açığa çıkartılması gerekmektedir.

Teknoloji ve bilimin insanın ihtiyaçları doğrultusunda gelişmesine paralel olarak, bu bilgilerin topluma aktarılmasının nitelikli eğitim programlarıyla mümkün olabileceği açıtır. Dolayısıyla öğretim programlarının çağın gereklerine ve toplumun istek, ihtiyaçlarına göre gözden geçirilmesi ve yenilenmesi gerekmektedir. Ertürk (1972), esasen bir denence olduğunu 
belirttiği tüm öğretim programlarının değerlendirilmesinin zorunluluğunu dile getirmiştir. Buna göre, programlar uygulanma aşamasında iken, sürekli olarak değerlendirilmekte ve program hedeflerinin ne derecede gerçekleştirildiği; temel sorunlarının ve eksikliklerin neler olduğu sorgulanmaktadır (Erden, 1992; Varış, 1996). Uzun ve Sağlam da (2003) çalışmalarında, lise biyoloji öğretim programının, zamanın getirdiği gelişmeler ve günümüzün koşullarına uygun olacak şekilde, her yıl üniversiteler ve Milli Eğitim Bakanlığı (MEB) işbirliği ile gözden geçirilerek geliştirilmesi gerektiğini bildirmişlerdir.

\section{Virüslerin Öğretimi}

Bireylerin hayatlarını devam ettirebilmesi için gerekli yaşamsal bilgilere ulaşabilmek adına biyoloji okuryazarlıklarının arttırılması gerekmektedir. Bu nedenle tüm düzeylerdeki okullarda biyoloji ve sağlık konularını içeren programlar dikkatle hazırlanmalı ve bu derslerin içeriği günün ihtiyaçlarına göre sürekli yenilenmelidir. Milli Eğitim Bakanlığı'mız (1998) da biyoloji öğretim programında, biyolojideki evrensel gelişmelerin genç bireylere aktarılabildiği ölçüde gelecekte başarılı, sağlıklı ve mutlu bir toplum olabileceğimizin altı çizilmektedir.

Virüslerin gezegenimiz üzerinde en bol çeşitliliğe sahip organizmalar arasında yer aldığı ve her türlü hücresel organizmayı enfekte edebildiği bilinmektedir. Bu durum özellikle virüs araştırmalarını ve bu doğrultuda yapılması gerekenleri ilginç kılmaktadır. Ayrıca virüslerin biyoteknolojik çalışmalardaki potansiyelleri (gen ekspresyonu ve gen terapisi gibi), hücresel olaylardaki genetik etkinlikleri, biyokimyaları ve viral hastalıkların oluşumu bilim insanlarının ve toplumun virüsler konusundaki bilgilenme isteklerinin nedenleri arasında sayılabilir (Madigan \& Martinko, 2012). En çarpıcı parazitler olarak karşımıza çıkan ve mikroskobik patojenleri oluşturan virüslerin insanlarda oluşturduğu hastalıklar çok çeşitli olup bazıları oldukça yaygın olarak bilinmektedir ( suçiçeği, kızamık, kuduz, grip, sarılık gibi ) (Lodish, Berk, Kaiser, Krieger, Scott, Bretscher, Ploegh \& Matsudaira, 2011).

Öğretimi açısından bakıldığında, virüs konusu, Türkiye'de 2005'te uygulanmaya başlanan öğretim programlarıyla ilköğretim kurumlarında fen ve teknoloji dersi kapsamında ve 6. sınıfta biyoloji alanına ilişkin konular içerisinde yer almıştır (MEB, 2005). Buna karşın en son uygulanan ilköğretim kurumları (ilkokullar ve ortaokullar) 3 - 8. sınıf fen bilimleri dersi öğretim programlarında virüslere ilişkin bilgiye yer verilmemektedir (MEB, 2013a). 2013 programından önceki dönemlerde öğrenim gören öğrenciler ilköğretimde edindikleri bu bilgilerle şu an ortaöğretimde öğrenim görmektedirler. Ortaöğretimde 2013 yılından itibaren 
uygulanan öğretim programlarında ise virüs konusu hem biyoloji (MEB, 2013) hem de sağlık bilgisi dersinin kazanımlarında karşımıza çıkmaktadır (MEB, 2012).

Araştırmalarda virüslerin, farklı yapıları nedeniyle anlaşılmalarının zor olduğu, virüs ve bakteri kavramlarının birbirine karıştırıldığı ve virüsler hakkındaki konuların öğrencilerde sık sık alternatif kavram oluşturacak şekilde ve kavram yanılgıları ile karşımıza çıktığı ifade edilmektedir (Uzunkaya, 2007; Gürler \& Önder, 2014). Bu kapsamda Uzunkaya (2007), çalışmasında 6. sınıf öğrencilerinin mikroorganizmalar konusunda; mikroorganizmaların bulundukları ortamları, etkileri, vücudumuzda varolan mikroorganizmaları, virüslerin ve bakterilerin canlılık özellikleri, mikroorganizmaların enfekte etme yolları, doğal ve yapay bağışıklık, aşının hastalıklara karşı koruyuculuğu ve antibiyotik kullanımı gibi konularda kavram yanılgıları olduğunu belirlemiştir. Dumais ve Hasni (2009) lise öğrencileriyle yaptıkları bir araştırmada, öğrencilerin gribin hücreleri etkileme yolları ve durumuyla ilgili yanlış anlamalara sahip olduklarını tespit etmişlerdir. Kurt ve Ekici (2013) de biyoloji öğretmen adaylarının virüslerin yapıları hakkında yeterli bilişsel yapılarının oluşmadığını ve virüsler hakkında kavram yanılgılarına sahip olduklarını ortaya koymuşlardır.

Günlük hayatımızı ve sağlığımızı büyük ölçüde etkileyen virüsler özellikle ortaöğretim düzeyindeki öğrenciler için ayrı bir önem taşımaktadırlar. İnsan İmmün Yetmezlik Virüsü (Human Immunodeficiency Virus-HIV, Acquired Immune Deficiency Syndrome-AIDS) vakalarının yaş dağılımlarına bakıldığında, bu hastaların beşte birinin yirmili yaşlarda olduğu ve 15-24 yaş grubunun ölüm nedenleri arasında AIDS hastalığının önemli bir yer tuttuğu görülmektedir (American Association for World Health (AAWH), 1994; Ekuklu \& Tokuc, 2009). Araştırmalara göre ergenlerin riskli cinsel davranışları bu hastalık için en önemli etkenlerden olduğundan ergenlere yönelik AIDS eğitiminin zorunlu olduğu düşüncesi ön plana çıkmaktadır (Harvey \& Spigner, 1995; Katz, Mills, Singh \& Best, 1995; Fisher \& Roffman, 1992; Ekici \& Kurt, 2014; Elkin, 2015). Çok (1998), araştırmasında özellikle ergen grubunu tehdit eden AIDS hastalığının önlenmesinde en önemli yolun eğitim olduğunu, ancak yeni çalışmalarda eğitimin, bilgi düzeyinin yükselmesi yerine, davranış değişikliği olarak değerlendirildiği durumda etkisinin azaldığını gösterdiği sonucuna varmıştır.

Bu çalışma, Ortaöğretim biyoloji ve sağlık bilgisi programlarının virüs konusu açısından ele alınıp, bu konuya ilişkin kazanımların değerlendirilmesi ve programdaki yerinin ortaya çıkarılması daha sonra yapılacak olan çalışmalar için katkı sağlayacak bir araştırma olarak önem taşımaktadır. Virüs salgınlarının günlük hayata etkisi, viral hastalıkların yarattığı tehlikeler, aş1lama önlemleri, biyoteknolojik potansiyelleri düşünüldüğünde, okulların bu 
konulara ilişkin öğrenmelerimize katkısının önemi ve yapılan çalışmanın alan yazınına sağlayacağı katkılar ortaya çıkmaktadır.

Virüslerin, insan hayatı için önemi ve hızla değişen yapıları göz önünde bulundurulduğunda öğretim programlarındaki yerlerinin de değerlendirilmesi kaçınılmaz bir gerekliliktir. Bu araştırmada ortaöğretim biyoloji ve sağlık bilgisi dersi öğretim programlarında yer alan virüs konusunun sınıf düzeyi, ders saati, içerik ve kazanımlar açısından incelenmesi amaçlanmıştır. Böylelikle ortaöğretimde virüslerin ele alışına dair yapı ortaya çıkarılmaya ve biyoloji/sağlı bilgisi öğretim programlarına katkıda bulunularak, potansiyel revizyon çalışmalarına destek sağlanmaya çalışılmıştır.

\section{YÖNTEM}

$\mathrm{Bu}$ araştırmada virüs konusunun öğretim programlarındaki yeri inceleneceğinden nitel araştırma yöntemlerinden doküman incelemesi kullanılmıştır. Doküman incelemesi, araştırılması istenen konu hakkında bilgi veren kitap, program (müfredat) yönergeleri, okul içi ve dışı yazışmalar, toplantı tutanakları, öğretmen dosyaları, resmi belgeler, vb. analizinin yapıldığı bir veri toplama biçimidir (Bogdan ve Biklen 1992; Goetz ve Le Compte, 1984. Akt. Yıldırım ve Şimşek, 2011). Farklı bilim insanları tarafından incelenebilen dokümanlar, varılan sonuçların ne denli geçerli olduğunun sorgulanmasını ve/veya daha önce ulaşılan sonuçlardan değişik sonuçlara ulaşılmasını da sağlayabilirler. Böylelikle, nitel araştırmaların tekrar edilebilir araştırma özelliği de sağlanmış olabilir (Marshall ve Rossman, 1995. Akt: Yıldırım ve Şimşek, 2011). Bailey’e göre (1994) sosyal bilim araştırmalarında sıklıkla karşılaşılan bir yöntem olan doküman incelemesinin güçlü yönleri arasında yüksek maliyetli olmayışı, uzun süreli analize olanak sağlaması gibi durumlar sayılabilmesine rağmen, olası yanlılık, ulaşılabilirlik, orjinallik kotrolü ve belli bir formata sahip olmaması gibi zayıf yönleri de bulunmaktadır (Akt: Çetinkaya \& Taşar, 2017). Bu araştırmada veri toplama süreci, doküman incelemesinin izlediği yol olan, incelenecek dokümana ulaşılması, dokümanın anlaşılarak verilerin analiz edilmesi ve verilerin raporlaştırılması şeklinde yapılmıştır.

\section{Veri Toplama Süreci}

Ortaöğretimde çalışma yapıldığı sırada uygulamasına devam edilen mevcut biyoloji ve sağlık bilgisi dersleri öğretim programlarına (uygulanmakta olan 5 farklı program) internet üzerinden Milli Eğitim Bakanlığı’nın resmi sitesinden erişim sağlanmıştır. 


\section{Veri Toplama Araçları}

Araştırmada doküman olarak, virüsler konusunun ortaöğretim programındaki yerini tespit etmek amacıyla biyoloji ve sağlık bilgisi ortaöğretim programları incelenmiştir. Araştırmada doküman olarak, 2016 yılında çalışmanın başladığı dönemde Milli Eğitim Bakanlığı (MEB) tarafından en son yayınlanan '’2012 Sağlık Bilgisi Dersi Öğretim Programı” ve '’2013 Ortaöğretim 9., 10., 11. ve 12. sınıf Biyoloji Dersi Öğretim Programı'”; çalışmanın devam ettiği 2019 yılında ise '’2017 Ortaöğretim Sağlık Bilgisi ve Trafik Kültürü Dersi Öğretim Programı’, ‘'2018 Ortaöğretim Sağlık Bilgisi ve Trafik Kültürü Dersi Öğretim Programı'” ve '2018 Ortaöğretim 9., 10., 11. ve 12. sınıf Biyoloji Dersi Öğretim Programı’” incelenmiştir.

\section{Verilerin Analizi}

Çalışmada elde edilen dokümanlar incelenirken içerik analizine tabii tutularak analiz edilmişlerdir. Çalışmada içerik analizi ortaöğretim biyoloji ve sağlık bilgisi dersi öğretim programlarında yer alan virüs konusunun sınıf düzeyi, ders saati, içerik ve kazanımlar açısından incelenmesi şeklinde gerçekleştirilmiştir. İçerik analizindeki temel amaç elde edilen verileri belirli çerçevede düzenlemek ve bu verileri açıklayabilecek kavramlara ulaşmaktır (Yıldırım \& Şimşek, 2011). Cohen, Manion ve Morrison (2007, s.475)ise içerik analizini en basit haliyle, yazılı verilerin özetlenmesi ve raporlanması süreci olarak tanımlanmaktadır. (Akt: Çetinkaya \& Taşar, 2017).

$\mathrm{Bu}$ çalışmada doküman incelemesinde araştırmacılar tarafından çalışmanın başladığı yıllar ve çalışmanın tamamlandığı yıllardaki güncel öğretim programları içerik analizine tabii tutulmuştur. Araştırmacılar tarafından dokümanlar incelenirken öğretim programlarının içerik analizi, virüslere ilişkin kazanımların, virüslere ayrılan sürenin (ders saati), virüslerin ele alındığı sınıf düzeyi ve zamanlamanın (dönem başı/dönem ortası/dönem sonu ), virüslerle ilgili kazanımlar ve ele alındığı ünitelerin tespit edilerek kategorize edilmesi şeklinde yapılmıştır.

\section{Geçerlik ve Güvenirlik}

Çalışmanın geçerlik ve güvenirliği sağlamak için araştırmacılar, araştırma yöntem ve aşamalarını açık bir biçimde anlatmışlar ve süreci net şekilde paylaşmışlardır. Büyüköztürk ve arkadaşlarına göre (2014), araştırmacıların tarafsızlığı araştırma geçerliğinin sağlayan en önemli faktörlerdendir. Bu nedenle bu çalışmada yanlılığı en aza indirmek için veriler iki araştırmacı tarafından analiz edilerek belirlenen özelliklere göre incelenmiştir. Bunun yanı sıra, araştırmanın başka araştırmacılar tarafından tekrar edilebilmesi için bu çalışmada incelenen öğretim programları kaynakça bölümünde web adresleri ile birlikte bildirilmiştir. 
Veri analizinde yanlılığı en aza indirgemek için analiz iki araştırmacı tarafından gerçekleştirimiştir. Bağımsız iki araştırmacının tarafındanbenzer kodları “Görüş Birliği”, farklı kodları ise "Görüş Ayrılı̆̆g’ şeklinde düşünülerek, çelişkili kodlarda araştırmacıların uzlaşması yoluna gidilmiş ve kodlamaya son hali verilmiştir. Kodlamalarda güvenirlik, Miles ve Huberman'ın, (1994) “Görüş birliğii/(Görüş birliği+Görüş ayrıllı̆ı) x 100” formülü kullanılarak, hesaplanmıştır. Buna göre, kodlayıcılar arasında uyum \%92 olarak tespit edilmiştir.

\section{BULGULAR VE YORUMLAR}

Bu bölümde çalışmanın başladığı yıllar ve çalışmanın tamamlandığı yıllardaki güncel biyoloji ve sağlık bilgisi dersleri öğretim programlarında virüsler hakkında yapılan analiz sonucunda elde edilen bulgular sunulmuştur. $\mathrm{Bu}$ bulgular, öğretim programlarında virüslere ilişkin kazanımların, virüslere ayrılan sürenin, virüslerin ele alındığı sınıf düzeyinin ve virüslerle ilgili kazanımların yer aldığı ünitelerin tespit edilmesi şeklinde ele alınmıştır.

\section{Ortaöğretim Biyoloji Dersi Öğretim Programında Virüsler}

Çalışmamızın bu kısmında biyoloji öğretim programları baz alınarak özellikle son yıllarda revize edilen programlar değerlendirmeye alınmıştır (Tablo 1). 2016 yılında başlanılan bu çalışma için öncelikli olarak MEB tarafından 2013 yılında yayınlanan ortaöğretim biyoloji dersi öğretim programı değerlendirilmiş, ardından bu süreç içerisinde yeni yayınlanan 2018 öğretim programı da ele alınmıştır.

Milli Eğitim Bakanlığı Talim ve Terbiye Kurulu Başkanlığı'nın 2013 yılında yayınladığı öğretim programı incelenerek virüslere ilişkin konuların ele alındığı sınıf düzeyi, konu için ayrılan ders saati, kazanımlar, ele alınan ünite başlıkları ve dönemsel olarak (dönem başı/sonu) bulunduğu yer tespit edilmeye çalışılmıştır. Bu bağlamda virüsler konusu 9. sınıflarda ' Canlı Alemleri ve Özellikleri' ünitesinde ele alınmıştır. Burada virüslerin genel özellikleri, viral hastalıklar, viral hastalıkların bulaşma yolları ve bu hastalıklardan korunma yollarının kazanım olarak ele alındığı saptanmıştır. Virüsler konusu ikinci dönemin ortasına denk gelecek şekilde yer almaktadır. Konu için 2 ders saati süresi ayrılmıştır. Bu bağlamda öğretim programında virüslere ilişkin yer alan kazanımlar şu şekildedir:

9.2.3.3. Virüslerin biyolojik sınıflandırma kategorilerinden herhangi biri içinde yer almamasının nedenlerini ve să̆lık üzerine etkilerini tartışır.

a. Virüslerin özellikleri, virüs kaynaklı hastalıkların insan hayatına etkileri temelinde tartışllır.

b. Virüslerin sebep olduğu herpes, AIDS, kuduz, hepatit, grip vb. hastalıkların bulaşma ve bu hastalıklardan korunma yollart irdelenir (MEB, 2013). 
Ortaöğretim biyoloji dersi öğretim programında 10. Sınıf kazanımlarında virüslere ilişkin konulara rastlanmamıştır.

Virüsler konusuna ilişkin alt başlıklardan viral hastalıklara 11. Sınıflarda 'Dolaşım Sistemi' ünitesinde değinilmiştir. Konu ikinci dönemin ortalarında ve 1 ders saatine yakın sürede ele alınmaktadır. Ünite içerisinde lenf dolaşımı başlığı altında virüsler konusuna yer verilen kazanımlar aşağıdaki gibidir:

11.2.5.4. Bağlşılklk çeşitlerini bilir, vücudun doğal koruma mekanizmalarının bulunduğunu fark eder.

a. Bağış̧ıllk, antijen, antikor, aşı, serum, interferon vb. kavramlar ünite içerisinde yeri geldikçe değerlendirilir.

b. Hastalık yapan organizmalar ve yabancı maddelere karşı vücudun oluşturduğu tepkiler örnekler (deri, tükürük, mide özsuyu, mukus ve gözyaşı) üzerinden ilişkilendirilir.

c. AIDS, Kırım-Kongo Kanamall Ateşi, grip gibi virütik hastalıklar ve alerji gibi bağışılklı sistemi rahatsızllkları araş̧ırılır (MEB, 2013).

Virüsler konusu dolaylı olarak 12. Sınıflarda ise "Genetik Şifre ve Protein Sentezi", ünitesi altında genetik mühendisliği ve biyoteknoloji uygulamaları konusunda ele alınmıştır. Zamanlama olarak birinci dönemin başında ve yaklaşık olarak 1 ders saatine yakın sürede işlenmektedir. Virüslere ilişkin interferon üretimi, kanser tedavisi gibi başlıklara yer verilmiştir. $\mathrm{Bu}$ bağlamda yer alan kazanımlar şu şekildedir:

12.1.2.4. Genetik mühendisliği ve biyoteknoloji uygulamalarının sağllk ve ekonomiye katkllarını irdeler.

a. Aşı, antibiyotik, insülin, interferon üretimi, kanser tedavisi uygulamaları araştırıllır.

b. Gen terapisi araştırllır.

c. Klonlama çalışmaları ve genetiği değiştirilmiş organizmaların olası sonuçları değerlendirilir.

ç. Biyogüvenlik ve biyoetik konuları araştırılır ve tartışılır (MEB, 2013).

Milli Eğitim Bakanlığı Talim ve Terbiye Kurulu Başkanlığı'nın 2018 yılında yayınladığı ortaöğretim biyoloji dersi öğretim programı incelendiğinde virüsler konusu 9. sınıflarda ' 'Canlı Alemleri ve Özellikleri', ünitesinde ele alınmaktadır. Konuya zamanlama olarak ikinci dönemin sonunda ve yaklaşık 1-2 ders saati içerisinde yer verilmektedir. Virüsler konusuna ilişkin olarak virüslerin genel özellikleri, insan sağlığına etkileri, viral hastalıklar, bu hastalıklara karşı alınabilecek önlemler ve genetik mühendisliği açısından avantajlı yönlerine yer verildiği tespit edilmiştir. Öğretim programında konuya ilişkin yer alan kazanımlar şu şekildedir:

9.3.2.3. Virüslerin genel özelliklerini açıklar.

a. Virüslerin biyolojik sınıflandırma kategorileri içine alınmamasının nedenleri üzerinde durulur.

b. Virüslerin insan sağlığ üzerine etkilerinin kuduz, hepatit, grip, uçuk ve AIDS hastalıklarl üzerinden tartışılması sağlanır. Virütik hastalıklara karşı alınacak önlemler vurgulanır.

c. Virüslerin genetik mühendisliği alanında yapılan çalışmalar için yeni imkânlar sunduğu vurgulanır (MEB, 2018).

Biyoloji dersi öğretim programında 10. sınıflarda virüslere ilişkin kazanım bulunmamaktadir. 
11. sınıflarda virüsler konusu ''Dolaşım Sistemi' ünitesinde ele alınmaktadır. Öğretim programına göre virüslere ilişkin konulara birinci dönemin sonlarında ve 1 ders saati süresince yer verilmektedir. Bağışıklık çeşitleri ve vücudun doğal savunma mekanizmaları konusu altında virüslere dolaylı olarak çok az yer verildiği saptanmıştır. Konuya ilişkin öğretim programında yer verilen kazanımlar aşağıdaki gibidir:

11.1.4.5.Bağışıklık çeşitlerini ve vücudun doğal savunma mekanizmalarını açıklar.

a. Hastalık yapan organizmalar ve yabancı maddelere karşı deri, tükürük, mide öz suyu, mukus ve gözyaşının vücut savunmasindaki rolleri örneklendirilir.

b. Enfeksiyon ve alerji gibi durumların bağışıklık ile ilişkisi örnekler üzerinden açıklanır.

c. İmmünoglobulinler verilmez.

ç. Aşılanmanın önemi üzerinde durulur. Bazı aşıların zaman içerisinde değişstirilmesinin nedenleri araştırilır.

d. Hastalık yapan organizmaların genetik yapılarının hızlı değişimi nedeniyle insan sağglığına sürekli bir tehdit oluşturduğu vurgulanır (MEB, 2018).

Virüsler konusuna 12. Sinıflarda ise "Genden Proteine', ünitesinde genetik şifre ve protein sentezi konusu bağlamında değinilmektedir. Zamanlama olarak birinci dönemin başına denk gelmektedir ve bu konu için yaklaşık olarak 1 ders saati ayrılmaktadır. Genetik mühendisliği ve biyoteknoloji uygulamalarının insan hayatına etkisi başlığı altında virüslere değinilen kazanımlar şu şekildedir:

12.1.2.4. Genetik mühendisliği ve biyoteknoloji uygulamalarının insan hayatına etkisini değerlendirir.

a. Aşı, antibiyotik, insülin, interferon üretimi, kanser tedavisi ve gen terapisi uygulamaları kısaca açıklanır.

b. Klonlama çalışmalarının ve organizmaların genetiğinin değiştirilmesinin olası sonuçları belirtilir. Ian Wilmut'un klonlama ile ilgili çallş̧masina değinilir.

c. Biyogüvenlik ve biyoetik konularının tartışllması sağlanır.

c. Sosyo-ekonomik ve kültürel bağlamın, biyolojinin gelişimini etkilediği vurgulanır (MEB, 2018).

MEB tarafından 2013 ve 2018 yıllarından itibaren uygulanan biyoloji öğretim programlarının, sınıf ve zamanlama, ünite, kazanım ve ders saati şeklinde kategorilendirilmiş hali ile yapılan karşılaştırmalı içerik analizinin sonuçları Tablo 1'de gösterilmektedir. 
Takmaz, S. \& Yılmaz, M. (2020). Virüs konusunun ortaöğretim ögrretim programlarındaki yeri, Anadolu Öğretmen Dergisi, 4(1), 21-43.

Tablo 1. 2013 ve 2018 Yılları Biyoloji Öğretim Programlarının (BÖP) Virüs Konusuna İlişkin İçerik Analizi Sonuçları

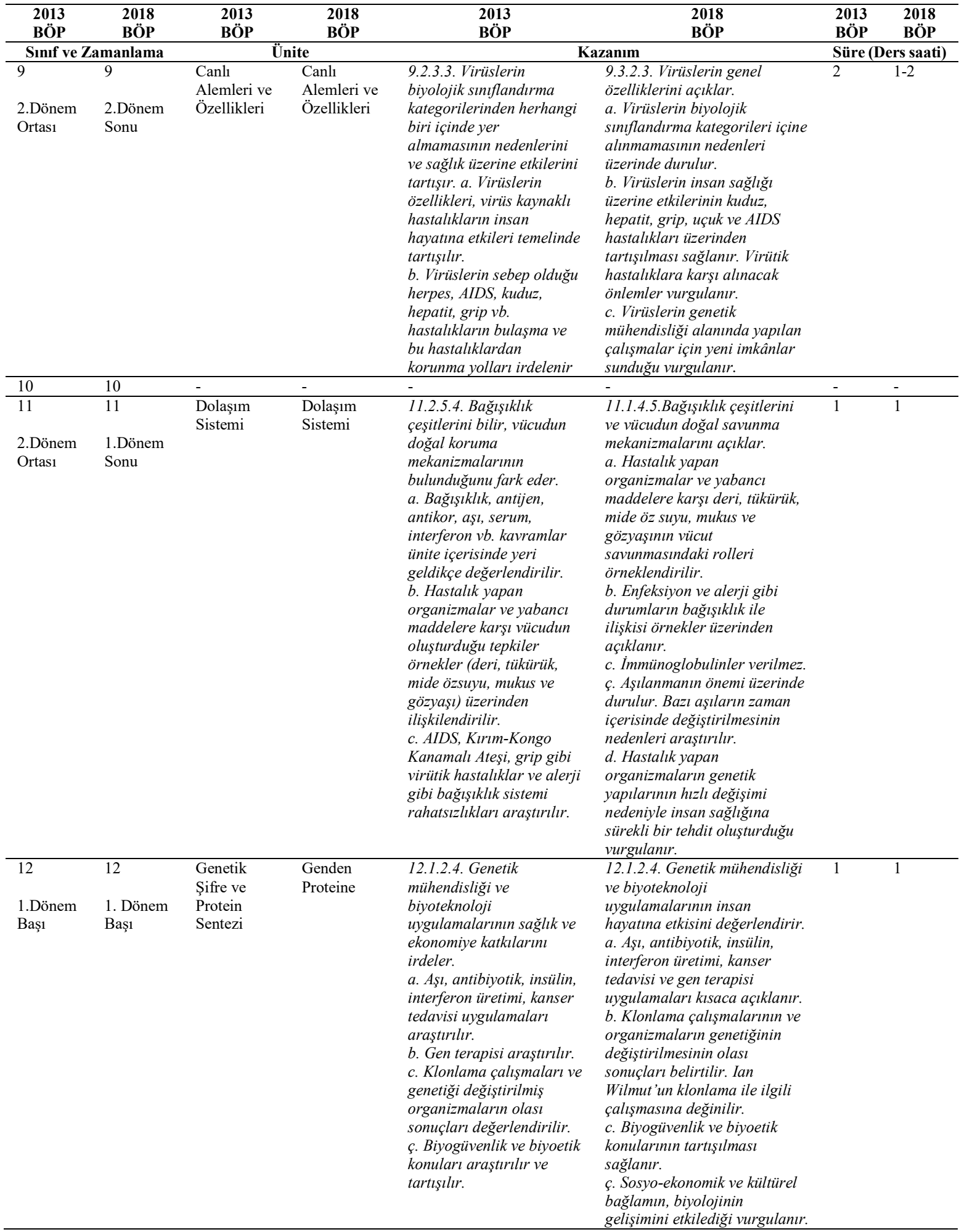

\section{Ortaöğretim Sağlık Bilgisi ve Trafik Kültürü Dersi Öğretim Programında Virüsler}

Sağlık bilgisi dersi kapsamında virüsler, viral hastalıklar ve viral aşılara ilişkin kazanımlara yer verilmiştir. Sağlık bilgisi dersi öğretim programında öğrencinin katılımını 
gerektiren uygulamalara yer verilmiştir. Bunlar, bireysel farklılıklara duyarlı ve bağımsız öğrenmeyi teşvik eden öğretim tekniklerini okul dışına da taşıyan niteliktedir (Aydın, 2014). Program, öğrencilere sağlıkla ilgili tutum ve becerileri kazandırmanın yanında, onların yeni bilgiler edinme ve sorunlara çözüm üretmeyi alışkanlık haline getirmelerini de amaçlamaktadır. "Sağlık Bilgisi” dersinde, ders öğretmeninin de göstereceği duyarlılık ile sağlık konusunda öğrencilerin yanlış inanış, tutum ve davranışlarının değiştirilmesi; sağlığını koruyabilmesi böylece sağlık konusunda doğru davranış becerisi kazanmış sağlıklı bireylerin topluma ve ülkeye kazandırılması hedeflenmiştir.

Sağlık bilgisi dersi öğretim programında biyoloji alanına ilişkin kazanımlara yer verilmesi ve viral hastalıkları ele alması bakımından hem öğrenciler hem de öğretmenler açısından gerekli görülmektedir. Biyoloji konuları ile ilişkili olarak oluşturulan ve ortaöğretim okullarında uygulanan sağlık bilgisi dersi öğretim programları da günümüze kadar birçok kez revize edilmiştir. Bu revizyonların günün ihtiyaçlarına uygun olarak yapılması gerektiği açıktır ve incelenmeyi gerektirmektedir. Bu çalışmanın öncesinde 2012 yılında yayınlanan ve o dönemlerde uygulanmakta olan öğretim programından sonra günümüze kadar 2017 ve son olarak 2018 yıllarında öğretim programında değişikliklere gidilmiştir (Tablo 2).

Milli Eğitim Bakanlığı Mesleki ve Teknik Eğitim Genel Müdürlüğü’nün 2012'de yayınlanan ortaöğretim sağlık bilgisi dersi öğretim programında virüslere ilişkin konuların zamanlama olarak ikinci dönemin sonlarına doğru ve yaklaşık olarak 9 ders saati yer verildiği tespit edilmiştir. 2012 yılı ortaöğretim sağlık bilgisi dersi öğretim programında virüslere ilişkin konulara dolaylı olarak yer verildiği saptanmıştır. 9. sınıflarda yer alan sağlık bilgisi dersinde virüsler konusuna “'Aile Hayatı ve Ana-Çocuk Sağlı̆̆ı"' ünitesinde aşı takvimi konusunda dolaylı olarak değinilmiştir. Bu konuya ilişkin öğretim programında yer alan kazanım şu şekildedir:

11. Çocukluk dönemi hastalıklarını önlemede aşı yaptırmanın önemini açıklar (MEB, 2012).

Ayrıca 'Hastalıklarla İlgili Temel Kavramlar ve İlkeler'” ünitesinde de viral hastalıklar ve bu hastalıkların bulaşma yollarına değinildiği tespit edilmiştir. İlgili konuya öğretim programında şu kazanımlar ile yer verilmektedir:

1. Kanserde erken tanı ve erken başvurunun önemini açıklar.

2. Kanserden korunma yollarinı siralar.

7. Bulaşıcı hastalıklarla ilgili kavramlarını açıklar.

8. Bulaşıcı hastalıkların bulaşma yollarını sıralar.

11. Temas yolu ile bulaşan hastalıkların genel özellikleri ve korunma yollarını açıklar.

12.Vektörlerle bulaşan hastalıkların genel özellikleri ve korunma yolların açıklar.

13. Hayvanlardan insanlara bulaşan hastalıkların genel özellikleri ve korunma yollarını açıklar.

14. Cinsel yolla bulaşan hastalıkların genel özellikleri ve korunma yollarını açılklar (MEB, 2012). 
2017 yılında Milli Eğitim Bakanlığı Ortaöğretim Genel Müdürlüğü’nün yayınladığı ortaöğretim sağlık bilgisi ve trafik kültürü dersi öğretim programında virüslere ilişkin konulara yer verildiği saptanmıştır. 9. Sınıflarda uygulanan öğretim programında virüslere ilişkin konulara birinci dönemin başında yer verildiği ve 2 ders saati süre ayrıldığı tespit edilmiştir. Dolaylı olarak ele alınan virüsler konusuna 'Kişisel ve Toplumsal Sağlık' ünitesinde yer verildiği görülmektedir. Öğretim programında bulaşıcı hastalıklar konusu altında yer verilen virüslere ilişkin kazanımlar şu şekildedir:

1.1.8. Bulaşıcı hastalıklardan korunma yollarını açıklar.

a. Bulaşıcı hastalıklardan genel korunma yolları açıklanır.

b. Bağışıklık ve aşı kavramları açıklanır.

c. Hayvanlardan insanlara bulaşabilecek hastalıkların genel özelliklerine ve bu hastalıklardan korunma yollarına değinilir.

ç. Kene ısırması durumunda yapılması gerekenler üzerinde durulur. Kırım-Kongo Kanamalı Ateşi'nin belirtilerine değinilir (MEB, 2017).

Milli Eğitim Bakanlığg tarafından 2018 yılında yayınlanan ortaöğretim sağlık bilgisi ve trafik kültürü dersi öğretim programında ise virüsler konusu ile ilgili 2017 yılında yayınlanan öğretim programı ile benzer kazanımlara yer verildiği saptanmıştır. Virüslere ilişkin konuların dolaylı olarak ele alındığı kazanımlara 'Kişisel ve Toplumsal Sağlık' ünitesinde yer verildiği, zamanlama olarak birinci dönemin başında ve 2 ders saati süresince yer verilmektedir. Virüslere ilişkin konulara 9. Sınıflarda uygulanan öğretim programında yer verilen kazanımlar aşağıdaki gibidir:

1.1.8. Bulaşıcı hastalıklardan korunma yollarını açıklar.

a. Bulaşıcı hastalıklardan genel korunma yolları açıklanır.

b. Bağışılklık ve aşı kavramları açıklanır.

c. Hayvanlar ve insanlarda ortak görülen bulaşıcı hastalıkların (zoonoz) genel özelliklerine ve bu hastalıklardan korunma yollarına değinilir. Zoonozlardan kuduz, brusella ve kuş gribi kısaca açıklanır.

ç. Kene ısırması durumunda yapılması gerekenler üzerinde durulur. Kırım-Kongo Kanamalı Ateşi' nin belirtilerine değinilir (MEB, 2018).

2018'de yayınlanan öğretim programında 2017 y1lında yayınlanan öğretim programındaki kazanımlara ilave olarak kuduz, kuş gribi gibi viral hastalıkların eklendiği tespit edilmiştir (MEB, 2018).

MEB tarafından 2012, 2107 ve 2018 yıllarından itibaren uygulanan sağlık bilgisi öğretim programlarının (SBÖP), sınıf ve zamanlama, ünite, kazanım ve ders saati şeklinde kategorilendirilmiş hali ile yapılan karşılaştırmalı içerik analizinin sonuçları Tablo 2'de gösterilmektedir. 
Takmaz, S. \& Yllmaz, M. (2020). Virüs konusunun ortaöğretim öğretim programlarındaki yeri, Anadolu Öğretmen Dergisi, 4(1), 21-43.

Tablo 2. 2012, 2017 Ve 2018 Yılları Sağlık Bilgisi Öğretim Programlarının (SBÖP) Virüs Konusuna İlişkin İçerik Analizi Sonuçları

\begin{tabular}{|c|c|c|c|c|c|c|c|}
\hline $\begin{array}{l}2012 \\
\text { SBÖP }\end{array}$ & $\begin{array}{c}2017 \\
\text { SBÖP ve } \\
2018 \\
\text { SBÖP }\end{array}$ & $\begin{array}{l}2012 \\
\text { SBÖP }\end{array}$ & $\begin{array}{c}2017 \\
\text { SBÖP ve } \\
2018 \\
\text { SBÖP }\end{array}$ & 2012 BSÖP & $\begin{array}{l}2017 \text { SBÖP ve } \\
2018 \text { SBÖP }\end{array}$ & $\begin{array}{c}2012 \\
\text { SBÖP }\end{array}$ & $\begin{array}{c}2017 \\
\text { SBÖP ve } \\
2018 \\
\text { SBÖP }\end{array}$ \\
\hline \multicolumn{2}{|c|}{ Sinıf ve Zamanlama } & \multicolumn{2}{|c|}{ Ünite } & \multicolumn{2}{|c|}{ Kazanım } & \multicolumn{2}{|c|}{ Süre (Ders saati) } \\
\hline 9 & 9 & $\begin{array}{l}\text { Aile } \\
\text { Hayatı ve }\end{array}$ & $\begin{array}{l}\text { Kişisel } \\
\text { ve }\end{array}$ & $\begin{array}{l}\text { 11. Çocukluk dönemi } \\
\text { hastalıklarını önlemede așl }\end{array}$ & $\begin{array}{l}\text { 1.1.8. Bulaşıcı hastalıklardan } \\
\text { korunma yollarını açıklar. }\end{array}$ & 9 & 2 \\
\hline $\begin{array}{l}\text { 2.Dönem } \\
\text { Sonu }\end{array}$ & $\begin{array}{l}\text { 1.Dönem } \\
\text { Baş1 }\end{array}$ & $\begin{array}{l}\text { Ana- } \\
\text { Çocuk } \\
\text { Sağlığı } \\
\\
\text { Hastalıkl } \\
\text { a İlgili } \\
\text { Temel } \\
\text { Kavramla } \\
\text { r ve } \\
\text { İlkeler }\end{array}$ & $\begin{array}{l}\text { Toplums } \\
\text { al Sağlık }\end{array}$ & 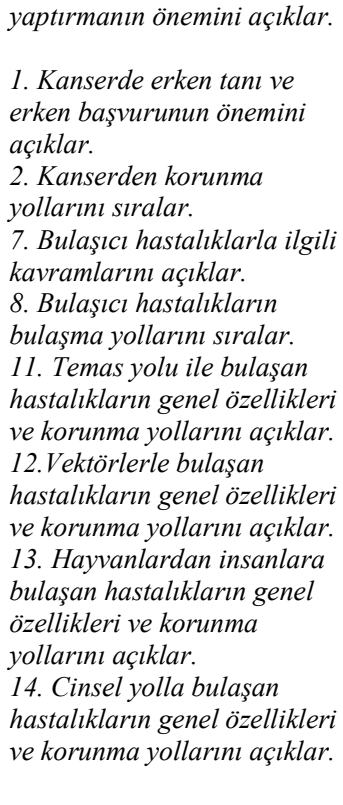 & 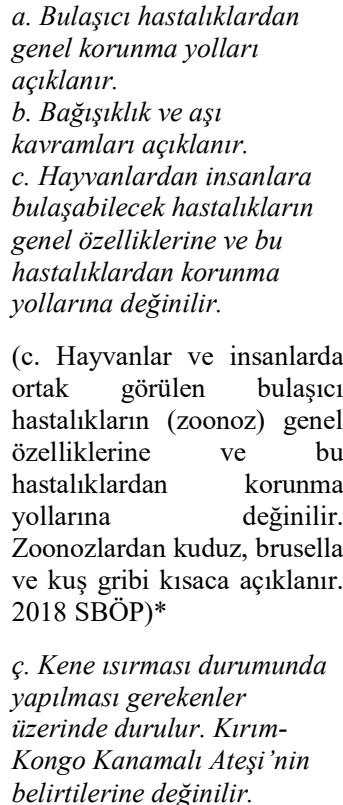 & & \\
\hline
\end{tabular}

*Bu kazanım 2018 yılı programının, 2017 yılı programından farklı olarak içerdiği tek kazanımdır.

\section{SONUÇ VE TARTIŞMA}

Bu çalışmada günümüze değin yenilenen öğretim programları temel alınarak özellikle son yıllarda revize edilen biyoloji ve sağlık bilgisi öğretim programları virüslere ilişkin kazanımların, virüslere ayrılan sürenin (ders saati), virüslerin ele alındığı sınıf düzeyi ve zamanlamanın (dönem başı/dönem ortası/dönem sonu ), virüslerle ilgili kazanımlar ve ele alındığı ünitelerin tespit edilerek kategorize edilmesi şeklinde değerlendirmeye alınmıştır. Öncelikli olarak MEB tarafından 2013 yılında yayınlanan ortaöğretim biyoloji dersi öğretim programı değerlendirilmiş, ardından 2018'de yayınlanan biyoloji dersi öğretim programı ele alınmıştır. Milli Eğitim Bakanlığı Talim ve Terbiye Kurulu Başkanlığı'nın 2013 yılında yayınladığı biyoloji dersi öğretim programı incelenerek virüslere ilişkin konuların ele alındığı sınıf düzeyi, konu için ayrılan ders saati, kazanım, kazanımların ele alındığı üniteler ve dönemsel olarak (dönem başı/sonu) bulunduğu yer tespit edilmeye çalışılmıştır.

Biyoloji öğretim programında virüslere ilişkin konuların 9. sınıflarda bir kazanım ile ele alındığı, bu kazanımda da virüslerin genel özellikleri, viral hastalıklar, bu hastalıkların bulaşma 
ve korunma yollarından bahsedilmektedir. Zamanlama olarak virüsler konusu ikinci dönemin ortalarına doğru denk gelmekte ve 2 ders saati kadar süre ayrılmaktadır. Öğrencilerin ergenlik çağı ve viral hastalıkların tehlikesi göz önünde bulundurulduğunda virüsler konusu için ayrılan sürenin oldukça yetersiz olduğu göze çarpmaktadır. Bunun yanı sıra kazanım sayısının azlığından dolayı detaylara ve virüslerin gündelik hayatla bağlantısının kurulmasına imkân verilmediği dikkati çekmektedir. Ünite olarak '’canlı alemleri ve özellikleri'’nde yer alması, virüslerin canlı/cansız olup olmamaları konusuna açıklık getirebilmek adına uygun olduğu düşünülmektedir. Zamanlamaya ilişkin olarak ikinci dönemin ortalarında ele alınması öğrencilerin hücre gibi bazı konulara en azından hâkim olması gerekliliğinden dolayı uygun olduğu düşünülmektedir.

10. sınıflarda virüsler konusuna ait hiçbir kazanım yer almamaktadır. Virüslere ilişkin konulara değinilmeksizin “hücre bölünmeleri”, “ekoloji” gibi üniteler öğretim programında ele alınmaktadır.

11. sınıflarda "dolaşım sistemi” ünitesinde aşı, interferon gibi kavramlar ile AIDS, grip gibi viral hastalıklara ilişkin sadece bir kazanım yer almaktadır. Zamanlama olarak ikinci dönemin ortalarında ve 1 ders saatinde ele alınmaktadır. "Bağışıklık sistemleri”" ile ilgili olarak ele alınan interferon, aşı üretimi ve viral hastalıklar için ünite başlığ 1 ve zamanlama olarak ikinci dönem ortasında yer almasının uygun olduğu düşünülmektedir. Fakat kazanım sayısının az ve ayrılan sürenin de yetersiz olduğu görülmektedir. Bu kısıtlamalardan ötürü interferon gibi önemli kavramların daha yüzeysel geçildiği düşünülmektedir.

12. sınıflarda ise "genetik şifre ve protein sentezi" ünitesi altında genetik mühendisliği ve biyoteknoloji uygulamaları konusunda virüslere ilişkin bir kazanım yer almaktadır. Virüslere ilişkin aşı, interferon üretimi, kanser tedavisi gibi konu başlıkları ele alınmaktadır. Bu konular zamanlama olarak birinci dönemin başında ve 1 ders saati süresince işlenmektedir. Ünite başlı $\breve{g ̆}_{1}$ derslerde virüslerin dezavantajlarının yanı sıra avantajlarına da değinebilmek adına uygundur. Virüslerin biyoteknolojik uygulamalarda kullanım alanlarına yer verilebilir ve öğrenciler için virüsler konusu daha da ilgi çekici hale getirebilir. Fakat kazanım ve süre yetersizliğinden dolayı yüzeysel olarak konunun işlenmek zorunda kalındığı düşünülmektedir. Bu konuda Çetin ve Başbay (2015)'ın yaptığı çalışmada 2016-2017 eğitim öğretim yılından itibaren uygulanacak olan yeni 12. sınıf biyoloji dersi öğretim programında içeriğin değişmesine paralel olarak haftada 3 saat için toplam 29 adet kazanım bulunmaktadır. Kazanım sayısının azalması hem üniversite sınavına hazırlanan öğrenciler hem de programı yetiştirmekte zorlanan öğretmenler açısından olumlu bir gelişme olarak görülebilir. 
2018 yılında yayınlanan ortaöğretim biyoloji dersi öğretim programında konu içeriklerinin azaltılması, ünitelerin yerlerinin sınıf düzeyinde değiştirilmesi ve bazı konuların çıkarılması açısından birtakım farklılıklar olduğu göze çarpmaktadır. Yapılan çalışmalarda da bu duruma ilişkin benzerlikler görülmektedir (Aşçı, Baştürk, Çebi, Delice, Kabapınar, Kabapınar, Kaptan, Güvendi Kaptan, Kılıç, Mozakoğlu, Oral \& Yangın, 2005; Baran, 2006). Fakat virüsler konusu bağlamında 2018 yılında revize edilen programın, 2013 yılındaki programa benzer olduğu dikkati çekmektedir. Bununla beraber 2018'de en son yayınlanan öğretim programında güncel olaylara ve konuların gündelik hayat ile ilişkilendirilmesine daha çok dikkat edilmiştir (MEB, 2018).

Biyoloji öğretim programı incelendiğinde virüslere ilişkin konuların 9. sınıflarda “canlı âlemleri ve özellikleri” ünitesinde bir kazanım ile ele alındığı ve 1-2 ders saati sürenin ayrıldığ anlaşılmaktadır. Zamanlama olarak virüslere ilişkin konuların ikinci dönemin sonlarına denk geldiği görülmektedir. 2013 yılına göre virüslerin dezavantajlarının yanı sıra kısmen avantajlarına da yer verildiği dikkati çekmektedir. Dolayısıyla 2018 yılındaki öğretim programında genetik mühendisliği alanında virüslerin kullanımının ele alındığı görülmektedir (MEB, 2018).

10. sınıflarda ise eski programdaki (2013 yılı ortaöğretim biyoloji dersi öğretim programı) gibi virüslere konusuna ilişkin kazanım yer almamaktadır (MEB, 2013a). "Hücre bölünmeleri”, "kalıtım ve ekosistem ekolojisi” ünitelerinin ele alındığı 10. sınıflarda virüsler konusuna rastlanmamıştır.

11. sınıflarda "dolaşım sistemi” ünitesinde bağışıklık konusunda bir kazanım ile 1 ders saati süresince ele alınmaktadır. Zamanlama olarak birinci dönemin sonlarında işlenmektedir. Aşılanmanın önemi ve aşıların sürekli değiştirilmek zorunda olunduğu üzerinde durulmaktadır. Bunun yanı sıra hastalıklara sebep olan organizmaların hızlı bir şekilde mutasyona uğramaları dolayısıyla insan sağlığını tehdit etmelerine değinilmektedir. 2013 yılında yayınlanan öğretim programında interferon ve AIDS, grip gibi viral hastalıklar daha yoğun bir şekilde ele alınırken, 2018 yılında yayınlanan öğretim programında daha çok hastalıklara sebep olan mikroorganizmaların sürekli yapı değiştirmeleri üzerinde durulmuştur. Dolayısıyla virüslere ilişkin interferon gibi önemli kavramlara bağışıklık sistemi konusunda değinilmediği anlaşılmaktadır. Sıcaker ve Öz Aydın (2015)'e göre de interferon kavramı “virüslerin genel özellikleri” ünitesinde anlatılsa bile bu kavramın zor olarak değerlendirilmesi geçmiş konulardan bilgi aktarımının olmadığını kanıtlar niteliktedir. Öğrenciler için anlamlı öğrenmenin gerçekleşebilmesi için öğrenecekleri kavramlar ile halihazırdaki mevcut 
bilgilerinin ilişkilendirilebilmesi gerekmektedir (Ausubel, Novak \& Hanesian, 1968). Kazanım sayısı ve ders saati açısından 2013 ve 2018 yılı öğretim programlarında farklılıklar saptanmamıştır (MEB, 2013a; 2018). Efe ve Efe (2018)'de aynı şekilde iki öğretim programında da kazanımların anlama, uygulama ve çözümleme bilişsel boyutlarda da farklı olmadıklarını dile getirmişlerdir. Sönmez (2018)'de biyoloji öğretim programları revize edilse de, ders saatlerinin yetersiz olduğu fakat bu durumun değişmediğini ve bu konuda istikrarlı olunduğunu belirtmektedir. Yapılan çalışmalarda da biyoloji öğretmenlerinin öğretim programını uygulamada zamanın yetersiz olduğunu dile getirmişlerdir (Cerrah, 2002; Kurt \& Yıldırım, 2010). Virüslere ilişkin konular zamanlama olarak 2013 yılındaki öğretim programında ikinci dönem ortalarında ele alınırken 2018 yılındaki öğretim programında birinci dönemin ortalarında ele alınmaktadır. Virüslere ilişkin konulara 12. sınıflarda "genden proteine" ünitesi altında genetik mühendisliği ve biyoteknoloji uygulamalarında bir kazanım ile yer verilmektedir. Zamanlama olarak birinci dönemin başında ve 1 ders saati süresince ele alınmaktadır. Gen terapisi, kanser tedavisi, interferon üretimi ve aşı gibi konular bağlamında virüsler işlenmektedir. Kazanım sayısı, zamanlama olarak birinci dönem başında ve 1 ders saatinde ele alınıyor olması açısından 2013 ve 2018 yılında yayınlanan öğretim programları arasında fark görülmemektedir.

2013 ve 2018 yıllarında yayınlanan ortaöğretim biyoloji dersi öğretim programlarının değerlendirilmesiyle varılan sonuçlardan biri virüsler konusuna ilişkin yeterli kazanım sayısının olmamasıdır. 9, 11 ve 12. sınıflarda birer kazanım bulunmakta, 10. sınıflarda ise virüslere ilişkin hiç kazanım bulunmamaktadır. Dolayısıyla virüsler hakkında aktarılmak istenilen bilgi için kısıtlayıcı bir unsur olarak kazanım sayısının yetersizliği görülebilir. Kazanımların sayı bakımından yetersizliğinin dışında literatüre bakıldığında 2013 ve 2018 biyoloji öğretim programlarında kazanımların açık ve anlaşılır olduğu ifade edilmektedir (Aydoğdu, 2010; Ergin, 2010; Koçakoğlu, 2016). Bunun dışında özellikle virüsler hakkında en temel bilgilerin aktarılacağı 9. sınıflarda konunun ikinci dönemin sonlarına denk gelmesi konunun aktarılması açısından dezavantajı bir durum yaratmaktadır. Dezavantaj yaratmasının sebebi ise dönem sonlarına doğru öğrencilerin genellikle motivasyonlarının düşmesi, konuların yetiştirilememesi gibi durumlardır. Akkaya, Tezcan, Karaca ve Seylim (2011)'in de yaptı̆̆ çalışmalarda dile getirildiği gibi fotosentez ve virüsler gibi bazı konuların yerlerinin değiştirilmesi gerekebilmektedir. Virüsler konusuna ayrilan sürenin 1-2 ders saati olması da konuyu öğrenciye aktarmak açısından oldukça yetersiz görünmektedir. Çevik ve Atıcı (2015) da yaptığı çalışmada biyoloji öğretmenlerinin biyoloji dersi öğretim programının içeriğinin, 
kazanımlarının uygulanabilmesi için sürenin yetersiz olduğunu belirtmişlerdir. Literatürde birçok araştırmada da özellikle 9. sınıflarda biyoloji dersi haftalık ders saati yetersiz bulunmuştur (Aydoğdu, 2010; Ayyıldız, 2010; Ergin, 2010; Karal, 2010; Kurt \& Y1ldırım, 2010). Bunların yanı sıra özellikle 2013 yılındaki öğretim programında virüslere ilişkin konuların oldukça yüzeysel kazanımlarla yer aldığı, insan sağlığına etkileri bakımından önem taşıyan viral hastalıkların tedavi yöntemlerinden bahsedilmemesi dikkati çekmektedir. Ayrıca virüslerin sadece dezavantajlarından bahsedilerek genetik mühendisliği ve biyoteknolojide kullanım alanlarına değinilmemektedir. Oysa ki Berkant (2005) çalışmasında özellikle gen tedavisinde virüs gibi vektörlerin kullanarak hatalı genlerin doğru kopyalarını konakçılara aktarmada kullanılabildiğini ifade etmektedir. Sıcaker ve Öz Aydın (2015) da çalışmalarında öğretmenlerin biyoteknoloji konusunda uygulamalı çalışmalarla dersi desteklemesi gerektiğini düşünmektedirler. MEB'in 2018 yılındaki öğretim programlarına bakıldığında ise viral hastalıkların tedavi süreçlerine değinilmediği fakat kazanım açıklamalarına bakıldığında az da olsa genetik mühendisliği alanındaki çalışmalarda virüslerin yeni imkânlar sunduğundan bahsedildiği görülmektedir. Literatüre bakıldığında Özatlı (2018), 2018 öğretim programının, 2013 öğretim programına göre daha sade ve sağlık sorunlarına, bilim insanlarının çalışmalarına yer vermesi açısından doğru bir yaklaşımda olduğunu belirtmektedir.

9. sınıflarda yer alan ve genellikle biyoloji öğretmenleri tarafından anlatılan sağlık bilgisi ve trafik kültürü dersi öğretim programları da içerik açısından önem teşkil ettiği için incelenmiştir. Bu çalışmanın yazım süresince 2012, 2017 ve 2018 yıllarında yayınlanan ortaöğretim sağlık bilgisi ve trafik kültürü dersi öğretim programları kazanım sayısı, konu başlığı, zamanlama ve süre olarak değerlendirilmiştir. 2012 yılında Milli Eğitim Bakanlığı Mesleki ve Teknik Eğitim Genel Müdürlüğü tarafından yayınlanan ortaöğretim sağlık bilgisi dersi öğretim programında "aile hayatı ve ana-çocuk sağlı̆̆ı" ünitesinde yer verilen bir kazanımla virüslere değinilmiştir. Hastalıkları önlemede aşının öneminin ele alındığı kazanımda viral hastalıkların da yer aldığı düşünülmektedir. Bunun yanı sıra "hastalıklarla ilgili temel kavramlar ve ilkeler" ünitesinde virüslere ilişkin konulara dolaylı olarak değinilen 8 kazanım yer almaktadır. Bu kazanımlarda genel olarak virüs kökenli hastalıkların genel özellikleri, bulaşma ve korunma yolları ele alınmaktadır. Bu kazanımlar zamanlama olarak ikinci dönemin sonlarına denk gelmekte ve kazanımlar için yaklaşık olarak 9 ders saati ayrıldığ görülmektedir. Sağlık bilgisi dersi açısından viral hastalıklar için ayrılan ders saatinin yeterli olduğu ancak zamanlama olarak ikinci dönem sonuna denk gelmesinin konuların yetişmemesi 
ve öğrenci motivasyonunun düşmesi açısından dezavantajlı bir durum yarattğı düşünülmektedir.

2017 y1lında Milli Eğitim Bakanlı̆̆ı Ortaöğretim Genel Müdürlüğ̈̈’nce yayınlanan ortaöğretim sağlık bilgisi ve trafik kültürü dersi öğretim programında "kişisel ve toplumsal sağlık" ünitesinde bulaşıcı hastalıklardan korunma yollarının açıklandığı bir kazanım ile virüslere ilişkin konulara dolaylı olarak yer verilmektedir. Burada bulaşıcı hastalıklardan korunma yolları, aşı ve bazı viral hastalıkların belirtilerine yer verilmektedir. Zamanlama olarak birinci dönemin başında yer alması avantajlı bir durum yaratsa da bu öğretim programında virüslere ilişkin konular için yaklaşık olarak 2 ders saati süre verilmesi dezavantajlı bir durum yaratabilmektedir. 2012 yılında yayınlanan öğretim programına kıyasla virüslere ilişkin kazanımların oldukça azaltıldığı dikkati çekmektedir. Buna sebep olarak 2012 yılında dersin adının sağlık bilgisi iken 2017 yılında sağlık bilgisi ve trafik bilgisi olması gösterilebilir. Çünkü 2017 yılında trafik kültürünün eklenmesi ile sağlıkla ilgili konuların oldukça azaltıldığ görülmektedir.

2018 yılında ise Milli Eğitim Bakanlığı tarafından yayınlanan ortaöğretim sağlık bilgisi ve trafik kültürü dersi öğretim programında ise 2017 yılındaki öğretim programında olduğu gibi "kişisel ve toplumsal sağlık" ünitesi altında bir kazanımla virüslere ilişkin konulara yer verilmektedir. Zamanlama olarak birinci dönemin başında ve yaklaşık 2 ders saati süresince virüsler konusuna yer verilerek bu bağlamda 2017 y1lındaki öğretim programı oldukça benzeşmektedir. 2017'deki öğretim programına ek olarak kuduz, kuş gribi hayvandan insana bulaşabilecek viral hastalıklara yer verilmektedir. Fakat sağlık bilgisi dersi açısından oldukça önem taşıyan virüsler konusunun bu denli az kazanımla ve yetersiz ders saati ile ele alınması insan sağlığını tehdit edebilecek veya genetik mühendisliği açısından yarar sağlayabilecek bir konu olması açısından sakıncalı bir durum olarak görülmektedir. Literatüre bakıldığında Sağlam (1996), ortaöğretimde biyoloji öğretmenleri tarafından verilen sağlık bilgisi dersinin özenli bir şekilde hazırlanmasına rağmen öğretmenler ve öğrenciler tarafından yetersiz bulunduğunu tespit etmiştir. Bunun nedeni olarak öğretmenlerin bu ders hakkında bilgi eksiklikleri, biyoloji konuları ile aynı olduğu için konuların tekrara girmesi, deneysel çalışmaların yetersizliği ve teorik bilgilerin uygulamaya dökülmemesi gösterilmektedir.

Öğretim programlarının incelendiği bu çalışmada yıllar içerisinde programların sürekli revize edildiği görülmektedir. Başaran (1987)'a göre, okullarda uygulanan eğitim programları birçok sebeple çok sık değiştirilmekte, fakat çok az geliştirilmektedir. Cansaran (2004) da Türkiye'de öğretim programlarının iyileştirilmesinin çok yavaş olduğunu, fakat programlardaki 
değişimlerin çok hızlı olduğunu belirtmektedir. Koçakoğlu (2016) bu bağlamda öğretim programı geliştirme ve yenileme çalışmalarında ihtiyaç analizi ve eski öğretim programlarının incelenmesiyle elde edilen sonuçları dikkate alarak hareket edilmesi gerektiğini vurgulamaktadır. Kabadere (2010) ise öğretim programı değerlendirme sürecinde aksaklıkların hemen düzeltilip iyileştirme yoluna gidilmesi gerektiğini ifade etmektedir.

Çalışmamızda, hayatımıza etkileri gün geçtikçe artan virüslerin, örgün eğitim aracılığıyla öğretimi hakkındaki güncel durum ve buna bağlı olarak önümüzdeki yılların lise mezunlarının bilgilenme kaynakları açıklanmıştır. Buna göre, ülkemizde virüsler hakkında verilen genel bilgilenmenin, tüm lise öğrencilerinin ortak bir eğitim-öğretim programını takip ettikleri 9. sınıfta olduğu; sadece 11 ve 12. sınıflarda biyoloji dersini seçen öğrencilerin virüslerle ilgili bazı üst bilgilere ulaşabileceğine dikkat çekilmektedir.

\section{ÖNERÍLER}

Günümüzde insan hayatında gerek hastalıklar ve gerekse salgınların geniş etkileriyle oldukça önemli hale gelen virüslerin öğretim programlarındaki yerini ele alan çalışmamızdan elde edilen sonuçlara göre aşağıdaki öneriler geliştirilebilir:

- Biyoloji dersi öğretim programlarında virüslere ilişkin konulara ait kazanım sayısı ve ders süresi mümkün olduğunca arttırılmalıdır.

- Kazanımlar, virüsler konusunun günlük hayattaki yerini kapsayacak şekilde detaylandırılmalıdır.

- Tüm ortaöğretim öğrencilerinin 9. sınıfta biyoloji ve sağlık bilgisi dersini zorunlu olarak almaları nedeniyle, kazanımlar özellikle günümüzde yaşanan ve yaşanabilecek salgın hastalıklardan korunma önlemlerine yer verecek şekilde revize edilmelidir.

- Biyoloji öğretim programında virüsler konusu 9. sınıflarda ikinci dönemin sonuna denk geldiği için tam olarak ele alınamadığından, öğretim programında virüsler konusunun yeri değiştirilerek, virüslerin genel özelliklerinin anlatıldığı konunun 9. sınıfta dönem ortası veya dönem başına gelecek şekilde konulabilir. 10. sınıflarda ise özellikle "mayoz bölünme” ünitesinin devamında eşeyli üreme konusunda virüslere ilişkin hastalıklara yer verilmesi önerilebilir. 
- Öğretim programlarının uygulayıcıları olan öğretmenler için virüslerin özellikleri/potansiyelleri ve etkili öğretim yöntemlerinin açıklandığg hizmet içi eğitimler düzenlenebilir.

- Virüslerin sağlığımız ve hayatımıza etkilerinin bundan sonra giderek artabileceği göz önüne alınarak, toplumdaki farklı örneklem çeşit ve büyüklüklerinde, virüslerle ilgili bilgi ve davranışlarımızı geliştiren yeni ve detaylı araştırmaların uygulanması önerilebilir.

- Özellikle şuan yaşanmakta olan güncel viral hastalıklar gibi önceden de salgın şeklinde yaşanmış olan hastalıklar örnek olarak öğretim programlarında yer alabilir. Böylece öğrenciler açısından konunun önemi daha iyi kavranabilir.

- Öğretim programlarında konu anlatımlarının yanı sıra ilgi çekici, çarpıcı okuma metinleri ile zenginleştirilebilir.

- Yoğun bir şekilde gündemimizi oluşturan virüsler konusunu tüm yönleriyle öğretim programlarında ele almanın yanı sıra animasyonlar, videolar veya filmler ile destekleyerek öğrenciler için akılda kalıcılığı arttırılabilir.

Virüs konusunun insan hayatına etkileri göz önünde bulundurulduğunda, bu konunun programda ele alınışı incelenerek günün şartlarına göre düzenlenmesi önemli bir gereklilik haline gelmektedir. Gerçekten de hayatı ve sağlığımızı önemli derecede etkileyen bir konuya öğrenim yaşantımızda yer verilmesi, gelişmeler ve ihtiyaçlar doğrultusunda yeniden düzenlenmesi veya öğrencilere olumlu yansıyan kısımlarının değerlendirilerek ele alınması topluma faydalı şekilde yansıyacaktır.

\section{KAYNAKÇA}

Akkaya Ercan, S., Tezcan, F., Karaca, İ. \& Seylim, E. (2011). Biyoloji dersi ögretim programının ögretmen görüşlerine göre değerlendirilmesi. Sempozyum:1. Uluslarasrası Eğitim Programları ve Öğretim Kongresi.

American Association for World Health (AAWH) (1994). AIDS and families. Washington, D.C.: AAWH.

Aşçı, M., Bastürk, M., Çebi, A., Delice, A., Kabapınar, F., Kabapınar, Y., Kaptan, A. Y., Güvendi Kaptan, S., Kılıç, D., Mozakoglu, M., Oral, B. \& Yangın, B. (2005). Konu alanı ders kitabı incelemesi. Ankara: Pegem Akademi.

Ausubel, D., Novak, J. D. \& Hanesian, H. (1968). Educational psychology: a cognitive view. New York: Holt, Reinhart and Winston.

Aydın, M. (2014). Ĕgitim yönetimi (10. Baskl). Ankara: Gazi. 
Aydoğdu, E. (2010). Ortaögretim 9. sınıf biyoloji dersi yeni ögretim programına ilişkin öğretmen görüşleri (Trabzon ili örneği) (Yayınlanmamış yüksek lisans tezi). Karadeniz Teknik Üniversitesi Eğitim Bilimleri Enstitüsü, Trabzon.

Ayyıldız, Z. (2010). Yeni lise biyoloji ögretim programının ögretmen görüşlerine göre değerlendirilmesi (Yüksek lisans tezi). Abant İzzet Baysal Üniversitesi Sosyal Bilimler Enstitüsü, Bolu.

Baran, E. (2006). Lise 1 biyoloji ders kitapları arasındaki iletişim stratejilerinin karşılaştırılması üzerine bir araştırma (Yayınlanmış yüksek lisans tezi). Selçuk Üniversitesi Fen Bilimleri Enstitüsü, Konya.

Başaran, İ. E. (1987). Eğitime giriş (6. Baskı). Ankara.

Berkant, H. G. (2005). Ortaöğretim biyoloji öğretim programında klonlama konusunun kapsamı ve insan klonlamaya yönelik program önerisi. Çukurova Üniversitesi Sosyal Bilimler Enstitüsü Dergisi, 14(1).

Büyüköztürk, Ş., Çakmak Kılıç, E., Akgün, Ö. E., Karadeniz, Ş. \& Demirel, F. (2014). Bilimsel araştırma yöntemleri (18. Bask1). Ankara: Pegem.

Cansaran, A. (2004). Biyoloji öğretmenliği öğrencilerinin biyoloji öğretmenliği programı hakkında düşünceleri. Gazi Üniversitesi Gazi Eğitim Fakültesi Dergisi, 24(1), 1-21.

Cerrah, L. (2002). Meslek liselerindeki biyoloji öğretim programının değerlendirilmesi: Durum analizi ve öneriler (Yüksek lisans tezi). Karadeniz Teknik Üniversitesi Fen Bilimleri Enstitüsü, Trabzon.

Çetin, Y. \& Başbay, M. (2015). “Öğretmen ve öğrenci gözüyle on ikinci sınıf biyoloji dersi öğretim program1. Pamukkale University Journal of Education, 38, 115-130.

Çetinkaya, E. \& Taşar, M. F. (2017). Fen bilimleri eğitimi alanında Türkiye merkezli argümantasyon araştırmalarının çeşitli değişkenler açısından incelenmesi, Hacettepe Üniversitesi Eğitim Fakültesi Dergisi, 33, 2, 353-381.

Çevik, M. \& Atıcı, T. (2015). Mevcut biyoloji dersi öğretim programının mesleki ve teknik liselerde görevli öğretmen ve öğrenci görüşlerine göre değerlendirilmesi ve yeni bir taslak önerisi: Fotosentez konusu örneği. Gazi Üniversitesi Gazi Eğitim Fakültesi Dergisi, 35(3), 423-441.

Çok, F. (1998). Ergenler ve AIDS eğitimi. Ĕgitim ve Bilim, 22(107), 46-53.

Dumais, N. \& Hasni, A. (2009). High school intervention for influenza biology and epidemics/pandemics: Impact on conceptual understandig among adolescents. Life Sciences Education, 8, 62-71.

Duyan, V. \& Duyan, G. (2004). Okullarda HIV/AIDS. Türk HIV/AIDS Tip Dergisi, Nisan-MaylsHaziran, 1-8.

Efe, H. \& Efe, R. (2018). 9. sınıf biyoloji dersi öğretim programındaki kazanımların yenilenmiş Bloom Taksonomisi'ne göre karşılaştırılması: 2013, 2017 ve 2018 yılları. International Journal of New Trends in Arts, Sports \&Science Education, 7(3), 1-9.

Ekici, G. \& Kurt H. (2014). Öğretmen adaylarının “AIDS” kavramı konusundaki bilişsel yapıları: bağımsız kelime ilişkilendirme testi örneği. Türkiye Sosyal Araştırmalar Dergisi, 183(183), 267-306.

Ekuklu, G. \& Tokuc, B. (2009). Trakya üniversitesi tıp fakültesi öğrencilerinin HIV/AIDS konusundaki bilgi düzeyleri ve tutumları. Turkiye Klinikleri Journal of Medical Sciences, 29(6), 1598-1604. 
Elkin, N. (2015). Üniversite öğrencilerinin cinsel yolla bulaşan hastalıklar konusunda bilgilerinin araştırılması. Mersin Üniversitesi Sağllk Bilimleri Dergisi, 8(1), 1-14.

Erden, M. (1992). Eğitimde program değerlendirme. (3. Baskl). Ankara: An1.

Ergin, M. Ş. (2010). Ortaöğretim 9. sınıf fizik dersi öğretim programına ilişkin öğretmen görüşleri (Yayınlanmamış yüksek lisans tezi). Gazi Üniversitesi Eğitim Bilimleri Enstitüsü, Ankara.

Ertürk, S. (1972). Ĕgitimde program geliştirme. Ankara: Yelkentepe.

Fisher, W. A. \& Roffman, D. M. (1992). Adolescence: a risky time. Independent School, 59(51), $25-32$.

Gürler, N. H., \& Önder, İ. (2014). 7. sinıf ögrencilerinin fen ve teknoloji dersinde öğrendikleri "bakteri ve virüs" kavramlarını günlük yaşamla ilişkilendirme durumlarının belirlenmesi. III. Sakarya'da Eğitim Araştırmaları Kongresi, 80.

Harvey, S. M. \& Spigner, C. (1995). Factors associated with sexual behaviour among adolescents: a multivariate analysis. Adolescence, 30(118), 243-264.

Holtzman, D., Mathis, M. P., Kann, J. C. \& Kolbe, L. J. (1995). Trends in risk behaviours for HIV infection among U.S. high school students, 1989-1991. AIDS Education and Prevention, 7(3), 265-277.

Horasan, Y. (2012). İzmir ilinde görev yapan biyoloji öğretmenlerinin yeni biyoloji programı hakkındaki görüşlerinin değerlendirilmesi (Yayımlanmış yüksek lisans tezi). Dokuz Eylül Üniversitesi Eğitim Bilimleri Enstitüsü, İzmir.

Kabadere, T. (2010). Lise biyoloji öğretim programlarının cumhuriyetten günümüze değişimini etkileyen unsurlar ve analizleri (Yayımlanmamış doktora tezi). Gazi Üniversitesi Eğitim Bilimleri Enstitüsü, Ankara.

Karal, A. (2010). Yeni 9. sınıf fizik dersi müfredat programının fizik ögretmenleri tarafindan değerlendirilmesi (Mersin ili örneği) (Yayınlanmamış yüksek lisans tezi). Gazi Üniversitesi Eğitim Bilimleri Enstitüsü, Ankara.

Katz, R. C., Mills, K., Singh, N. N. \& Best, A. M. (1995). Knowledge and attitudes about AIDS: a comparison of public high school students, incarcerated delinquents, and emotionally disturbed adolescents. Journal of Youth and Adolescence, 24(1), 117-131.

Koçakoğlu, M. (2016). Ortaöğretim biyoloji dersi öğretim programının değerlendirilmesi. Necatibey Ĕgitim Fakültesi Elektronik Fen ve Matematik Ĕ̈itimi Dergisi, 10(2), 65-91.

Kurt, H. \& Ekici G. (2013). Virüs nedir? Biyoloji ögretmen adaylarının virüs konusundaki bilişsel yapılart. International Online Journal of Educational Sciences, 5(3), 736-756.

Kurt, S. \& Yıldırım, N. (2010). Ortaöğretim 9. sınıf kimya dersi öğretim programının uygulanması ile ilgili öğretmenlerin görüşleri. Ondokuz Mayıs Üniversitesi Eğitim Fakültesi Dergisi, 29(1), 91-104.

Lodish, H., Berk, A., Kaiser, C. A., Krieger, M., Scott, M. P., Bretscher, A., Ploegh, H. \& Matsudaira, P. (2011). Moleküler hücre biyolojisi (Ed. Freeman, W. H. \& Company). (H. Geçkil, M. Özmen \& Ö. Yeşilada, Çev.). Ankara: Palme.

Madigan, M. T. \& Martinko, J. M. (2012). Mikroorganizmaların biyolojisi (C. Çökmüş, Çev.). Ankara: Palme.

Milli Eğitim Bakanlığ1 (MEB) (1998). http://ogm.meb.gov.tr/programlar.aspx adresinden erişilmiştir.

Milli Eğitim Bakanlığı (MEB) (2005). http://ttkb.meb.gov.tr/www/ogretim-programlari/icerik/72 adresinden erişilmiştir. 
Milli Eğitim Bakanlığı (MEB) (2012). Ortaöğretim sağlık bilgisi dersi öğretim programı. http://ttkb.meb.gov.tr/program2.aspx adresinden erişilmiştir.

Milli Eğitim Bakanlığı (MEB) (2013). Ortaöğretim 9., 10., 11. ve 12. sinıf biyoloji öğretim program1. http://ttkb.meb.gov.tr/program2.aspx adresinden erişilmiştir.

Milli Eğitim Bakanlığı (MEB) (2013a). İlköğretim fen bilimleri dersi (3., 4., 5., 6., 7., 8.) öğretim program1. http://ttkb.meb.gov.tr/program2.aspx adresinden erişilmiştir.

Milli Eğitim Bakanlığı (MEB) (2017). Ortaöğretim sağlık bilgisi ve trafik kültürü dersi öğretim programı. http://mufredat.meb.gov.tr/Programlar.aspx adresinden erişilmiştir.

Milli Eğitim Bakanlığı (MEB) (2018). Ortaöğretim sağlık bilgisi ve trafik kültürü dersi öğretim program1. http://mufredat.meb.gov.tr/Programlar.aspx adresinden erişilmiştir.

Milli Eğitim Bakanlığı (MEB) (2018a). Ortaöğretim 9., 10., 11. ve 12. sınıflar biyoloji öğretim programı. http://mufredat.meb.gov.tr/Programlar.aspx adresinden erişilmiştir.

Öz Aydın, S., Şahin, S. \& Sicaker, A. (2013). The effect of protein synthesis game in the class on the students" understanding the subject of protein synthesis. In 5th World Conference on Educationl Sciences, Sapienza University.

Özatlı, S. N. (2018). Değişen biyoloji dersi öğretim programının incelenmesi. Uluslararası Necatibey Eğitim ve Sosyal Bilimler Araştırmalar Kongresi, IV(IV), Balıkesir.

Sağlam, N. (1996). Ortaöğretimde sağlık bilgisi dersinin niteliği ve öğrencilerin derse ilgileri. Hacettepe Üniversitesi Eğitim Fakültesi Dergisi, 12, 201-206.

Sıcaker, A. \& Öz Aydın, S. (2015). Ortaöğretim biyoteknoloji ve gen mühendisliği kavramlarının öğrenciler tarafından değerlendirilmesi. Ondokuz Mayız Üniversitesi Eğitim Fakültesi Dergisi, 34(2), 51-67.

Sönmez, S. (2018). Türkiye'de ortaöğretimde biyoloji öğretiminde yapılan ders içerikleri çalışmalarının değerlendirilmesi. Akademik Sosyal Araştırmalar Dergisi, 6(69), 128-144.

Topal, Ş. (2006). Biyogüvenlik ve biyoteknoloji. İstanbul: Cemturan Ofset.

Uzun, N. \& Sağlam, N. (2003). Orta Öğretim Biyoloji Programında Genetik Konularının Değerlendirilmesi ve Öğrencilerin Genetiğie Karşı İgisinin Saptanması, Hacettepe Üniversitesi Eğitim Fakültesi Dergisi, 24, 129-136.

Uzunkaya, A. (2007). Kavram Yanılgısı ve Çoklu Zeka Alanlarının İlişkilendirilmesine Dayalı Bir Öğretimin Kavram Yanılgılarının Giderilmesindeki Etkisinin İncelenmesi Mikroorganizmalar, Yüksek Lisans Tezi, Balıkesir Üniversitesi Fen Bilimleri Enstitüsü Ortaöğretim Fen ve Matematik Alanlar Eğitimi Anabilim Dalı, Balıkesir.

Varış, F. (1996). Eğitimde program geliştirme. Teori ve teknikler. Ankara: Alkım.

Yeşilyurt, S. \& Gül, Ş. (2008). Ortaöğretimde daha etkili bir biyoloji öğretimi için öğretmen ve öğrenci beklentileri. Kastamonu Eğitim Dergisi, 16(1), 145-162.

Yıldırım, A. \& Şimşek, H. (2011). Sosyal bilimlerde nitel araştırma yöntemleri. (6.Baskı). Ankara: Seçkin. 